\title{
ПРОМЫШЛЕННЫЕ ТИПЫ КАРБОНАТНЫХ ПОРОД ЭСТОНСКОЙ ССР
}

По наиболее общему характеру требований к качеству карбонатных пород все основные области их использования могут быть объединены в две крупные группы: I - отрасли, предъявляющие требования, в основном, к вещественному составу карбонатных пород, II - отрасли, для которых главное значение имеют их физико-механические свойства.

Первая группа охватывает большинство потребляющих карбонатные породы отраслей народного хозяйства - металлургическую, химическую, сахарную, целлюлозную, производство цемента, строительной извести и др. Ко второй группе относится промышленное, дорожное и жилищное строительство.

Автором в течении многих лет $(1967-1984)$ изучались проблемы распространения, состава, свойств и возможностей использования карбонатных пород палеозоя Эстонии (Тээдумяэ, 1983). Промышленная перспективность карбонатных пород обусловлена не только комплексом признаков, включающих физико-механические свойства, вещественный состав, структурно-текстурные особенности, но и характером пространст, венного размещения отдельных литологических разновидностей - их выдержанностью в плане и разрезе, мощностью, глубиной залегания.

С учетом всех этих признаков, а также генезиј'а, на территорин Әстонии автором выделено семь групп карбонатных пород, которые могут быть рассмотрены как литолого-промышленные типы. Они выделены по генетическо-структурным группам (Vingisaar jt., 1965), что дает возможность использовать фациальный анализ для выяснения пространственного размещения промышленно перспективных пород.

П ер вичны е доломиты. Несмотря на их ограниченное распространение (только в силуре на о-ве Сааремаа; см. рисунок) с ними связан один из своеобразнейших видов карбонатных полезных ископаемых Эстонии - декоративные облицовочные доломиты - каармаские и сельгазеские.

Каармаские доломиты - это глинистые доломиты с четко выраженной горизонтальной или пологоволнистой микрослоистостью, обусловленной ритмичным чередованием карбонатных и более глинистых слойков (Эйнасто, 1979). Общее содержание терригенного материала в большинстве случаев $10-15 \%$, их мощность не превышает 5,0 м. Благодаря толстослоистости $(0,5-2,0$ м) и возможности получения крупных монолитов они являются ценным сырьем для производства разных видов облицовочных плит и декоративных деталей. Прочностные свойства каармаских доломитов низкие (таблица), как строительный камень и сырье для щебня они неперспективны.

Сельгазеские доломиты обладают своеобразным узором (пятна и разводы мелкорассеянного пирита), ввиду чего известны под названием «узорчатые». Распространение их ограниченное - по мощности до 3 м, по латерали - до километра. 


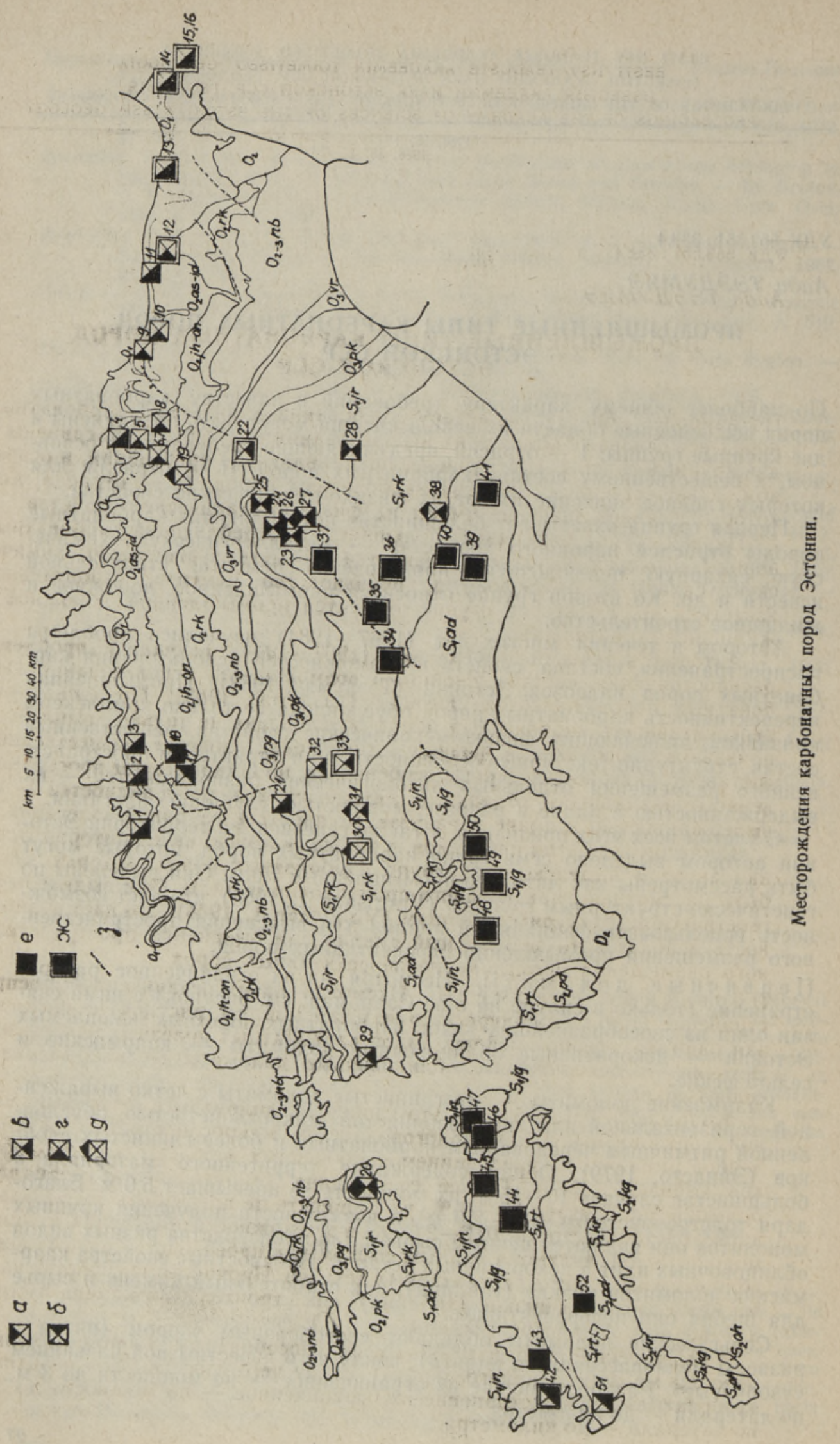


Прочностные свойства узорчатых доломитов (таблица) высокие, что позволяет использовать отходы производства облицовочных плит для производства щебня, а также в качестве строительного камня.

Би оморфны е из вестняки залегают в виде относительно невыдержанных прослоев и линз, и нередко постепенно переходят в детритовые. Только бореалисовый известняк распространен более широко и его мощность достигает $10 \mathrm{м}$.

Строматопоровые известняки не образуют выдержанных пластов и линз минимальной промышленной мощности (3 м). Однако в районах их совместного залегания с бореалисовым известняком и детритовыми известняками они вполне могут быть использованы (таблица).

Биоморфные известняки характеризуются высоким содержанием $\mathrm{CaO}(43-54 \%)$ и малой примесью нерастворимого остатка (н.о.) (обычно менее $3 \%$ ). Содержание $\mathrm{MgO}$ колеблется от 1 до $7 \%$ (Юргенсон, 1961). Повышенные содержания (более $3 \%$ ) окиси магния тесно связаны с процессами вторичной доломитизации, развитой в зонах тектонических нарушений.

Физико-механические свойства (таблица) биоморфных известняков зависят от крупности слагающих их скелетных образований. Бореалисовый известняк, сложенный крупными створками Pentamerus borealis, обладает низкими прочностными свойствами и соответствует сырью для щебня марки 300 и Мрз 15. Строматопоровые известняки отличаются более высокой прочностью и пригодны для щебня марок $800-600$ и Мрз 25.

В общем биоморфные известняки служат сырьем для производства извести, известкования кислых почв, подкормки птиц, а на участках вне зон доломитизации для целлюлозно-бумажной и металлургической промышленности.

Би огермны е из в естняки характерны для некоторых уровней (таблица). Размеры биогермов разные - от нескольких до сотен метров по поперечнику и мощностью до 15 м. Биогермы с поперечником несколько сотен метров (до километра) в сущности являются биогермными массивами, образовавшимися в результате срастания более мелких биогермов (Аалоэ, 1956).

Биогермные известняки отличаются высоким содержанием $\mathrm{CaO}$ $(43-55 \%)$. Колебание содержания $\mathrm{CaO}$ коррелируется с содержанием

Типы пород: $a$ - известняки биоморфные, $\sigma-$ известняки биогермные, $\theta-$ известняки детритовые, $2-$ нзвестняки илисто-детритовые, $\partial-$ известняки илистые, $e-$ доломиты первичные, ж- доломиты вторичные, 3 - линия тектонических нарушений. Месторождения: 1 - Харку, 2 - Вяо, 3 - Маарду, 4 - Курелийва, 5 - Кунда, 6 - Тоолсе, 7 - зап. берег р. Тоолсе, 8 - Ару (юж.), 9 - Азери, 10 - Ранну, $11-$ Сака, 12 - Кохтла-Ярве, 13 - Силламяэ, 14 - Нарва, $15-$ Қадастик, 16 - Нарва (вскрыша фосфоритов), 17 - Румму, $18-$ Падизе, $19-$ Раквере, 20 - Сууремыйза, 21 - Сикельди, 22 - Инью-Мерикюла, 23 - Аавере, 24 - Выхмута, 25 - Тамсалу, 26 - Қарину, 27 - Метсла, 28 - Ракке, 29 - Унгру-Сепакюла, 30 - Хаймре, 31 Лубья, 32 - Хыреда, 33 - Кеава, 34 - Тюри-Аллику, $35-$ Мюнди, 36 - Койги, 37 - Метсатагузе, 38 - Калана, 39 - Витсъярве, 40 - Адавере, 41 - Неанурме, 42 - Яагараху, 43 - Мустъяла, 44 - Тагавере, 45 - Лийгаласкма, 46 - Когува, 47 - Хелламаа, 48 - Михкли, 49 - Коонга, 50 - Анелема, 51 - Агама, 52 - Каарма. Индексы стратиграфических горизонтов: $\mathrm{O}_{1}$ - волховский, кундаский; $\mathrm{O}_{2}$ as-id - aзeриский, ласнамягиский, ухакуский, кукрузеский, идавереский; $\mathrm{O}_{2} \mathrm{jh}$-on — йыхвнский, кейлаский, оандуский; $\mathrm{O}_{2} \mathrm{rk}-$ раквереский; $\mathrm{O}_{2-3} \mathrm{nb}-$ набалаский; $\mathrm{O}_{3} \mathrm{vr}-$ вормсиский; $\mathrm{O}_{3} \mathrm{pg}$ - пиргуский; $\mathrm{O}_{3} \mathrm{pk}$ - поркуниский; $\mathrm{S}_{1} \mathrm{jr}$ - юуруский; $\mathrm{S}_{1} \mathrm{rk}$ - райккюлаский; $\mathrm{S}_{1} \mathrm{ad}$ - адавереский; $\mathrm{S}_{1} \mathrm{jn}$ - яаниский; $\mathrm{S}_{1} \mathrm{jg}$ - яагарахуский; $\mathrm{S}_{2} \mathrm{rt}$ - роотсикюлаский; $\mathrm{S}_{2} \mathrm{pd}$ - паадлаский; $\mathrm{S}_{2} \mathrm{kr}$ - курессаареский; $\mathrm{S}_{2} \mathrm{~kg}$ - каугатумаский; $\mathrm{S}_{2} \mathrm{oh}$ - охесаареский; $\mathrm{D}_{2}$ - средний девон. 
Характерные показатели физико-механических и технологических свойств литолого-промышленных типов карбонатных пород Эстонии

\begin{tabular}{|c|c|c|c|c|c|c|c|c|}
\hline 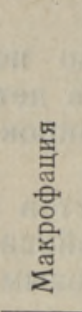 & 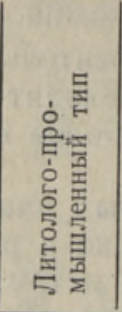 & 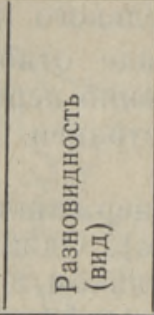 & $\begin{array}{l}\frac{1}{2} \\
\frac{1}{5} \\
5 \\
5 \\
0 \\
0 \\
5 \\
5 \\
5\end{array}$ & 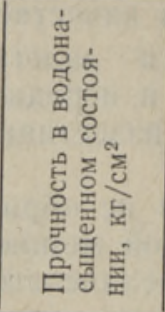 & 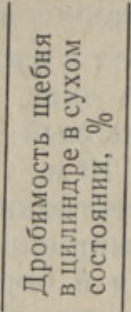 & 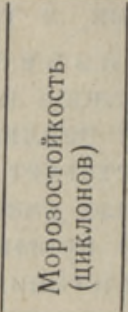 & 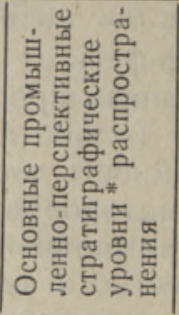 & 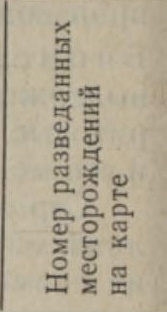 \\
\hline 1 & 2 & 3 & 4 & 5 & 6 & 7 & 8 & 9 \\
\hline \multirow{2}{*}{ 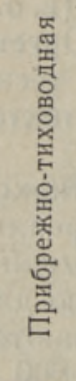 } & \multirow{2}{*}{$\begin{array}{l}\text { Доло- } \\
\text { миты } \\
\text { пер- } \\
\text { вич- } \\
\text { ные }\end{array}$} & $\begin{array}{l}\text { доломит } \\
\text { микро- } \\
\text { слойча- } \\
\text { тый } \\
\text { (каар- } \\
\text { маскнй) }\end{array}$ & $\begin{array}{l}2,10- \\
2,20\end{array}$ & $180-240$ & $24-27$ & $15-25$ & $\begin{array}{l}\mathrm{S}_{2} \mathrm{pdS}, \\
\mathrm{S}_{2} \mathrm{pdH}\end{array}$ & 52 \\
\hline & & $\begin{array}{l}\text { доломит } \\
\text { узорча- } \\
\text { тый } \\
\text { (сельга- } \\
\text { зеский) }\end{array}$ & $\begin{array}{l}2,20- \\
2,30\end{array}$ & $600-700$ & $\begin{array}{l}\text { не оп- } \\
\text { реде- } \\
\text { лена }\end{array}$ & 25 & $\begin{array}{l}\mathrm{S}_{1} \mathrm{jgSI}, \\
\mathrm{S}_{2} \mathrm{rtKn}, \\
\mathrm{S}_{2} \mathrm{rtVt}, \\
\mathrm{S}_{2} \mathrm{rtVs}\end{array}$ & 43 \\
\hline \multirow{6}{*}{ 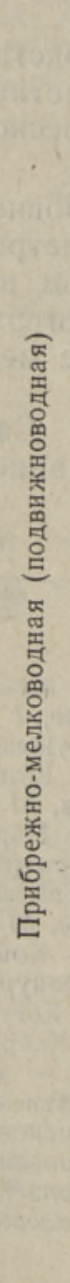 } & \multirow{2}{*}{$\begin{array}{l}\text { Извест- } \\
\text { няки } \\
\text { био- } \\
\text { морф- } \\
\text { ные }\end{array}$} & $\begin{array}{l}\text { извест- } \\
\text { няк бо- } \\
\text { реали- } \\
\text { совый } \\
\end{array}$ & $\begin{array}{l}2,55- \\
2,60\end{array}$ & $400-500$ & $20-28$ & 25 & $\mathrm{~S}_{1} \mathrm{jrTm}$ & $\begin{array}{l}20,23,24 \\
25,26,27 \\
28\end{array}$ \\
\hline & & $\begin{array}{l}\text { извест- } \\
\text { няк стро- } \\
\text { матопо- } \\
\text { ровый }\end{array}$ & $\begin{array}{l}2,60- \\
2,65\end{array}$ & $900-1000$ & $\begin{array}{l}\text { не оп- } \\
\text { реде- } \\
\text { лена }\end{array}$ & 25 & $S_{1} j \mathrm{rK}$ & $\begin{array}{l}23,24,26 \\
27\end{array}$ \\
\hline & \multirow{2}{*}{$\begin{array}{c}\text { Извест- } \\
\text { няки } \\
\text { бно- } \\
\text { герм- } \\
\text { ные }\end{array}$} & \begin{tabular}{|} 
извест- \\
няк бно- \\
гермный
\end{tabular} & $\begin{array}{l}2,50- \\
2,65\end{array}$ & $400-800$ & $15-24$ & 25 & $\mid \begin{array}{l}\mathrm{O}_{2} \mathrm{kl}+\text { on } \\
\mathrm{V}, \mathrm{O}_{3} \mathrm{pkR}, \\
\mathrm{S}_{1} \mathrm{jrH}, \\
\mathrm{S}_{1} \mathrm{jgP}, \\
\mathrm{S}_{2} \mathrm{pdK}\end{array}$ & $\begin{array}{l}17,18,20 \\
42,51\end{array}$ \\
\hline & & \begin{tabular}{|c} 
извест- \\
няк гли- \\
нистый \\
бно- \\
гермный
\end{tabular} & $\begin{array}{l}2,30- \\
2,60\end{array}$ & $400-600$ & $\begin{array}{l}\text { не оп- } \\
\text { реде- } \\
\text { лена }\end{array}$ & $15-25$ & $\mid \begin{array}{l}\mathrm{O}_{2} \mathrm{kl} \\
\mathrm{V}\end{array}$ & 17,18 \\
\hline & \multirow{2}{*}{$\begin{array}{l}\text { Извест- } \\
\text { няки } \\
\text { детри- } \\
\text { товые }\end{array}$} & $\begin{array}{l}\text { извест- } \\
\text { няк } \\
\text { крупно- } \\
\text { детрн- } \\
\text { товый }\end{array}$ & $\begin{array}{l}2,60- \\
2,65\end{array}$ & $400-600$ & $20-28$ & 25 & 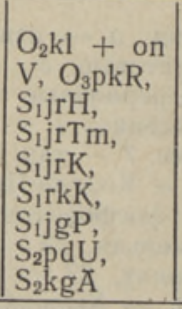 & $\begin{array}{l}17,18,20 \\
21,23,24, \\
25,26,27 \\
28,32,33 \\
38,51\end{array}$ \\
\hline & & $\begin{array}{l}\text { извест- } \\
\text { няк } \\
\text { мелко- } \\
\text { детрито- } \\
\text { вый }\end{array}$ & $\begin{array}{l}2,60- \\
2,70\end{array}$ & $800-1000$ & $14-24$ & 25 & $\begin{array}{l}\mathrm{O}_{1} \mathrm{vlS}, \\
\mathrm{O}_{1} \mathrm{vlKl}, \\
\mathrm{O}_{1} \mathrm{knUt}, \\
\mathrm{O}_{1} \mathrm{knVl}, \\
\mathrm{O}_{1} \mathrm{knNp}, \\
\mathrm{O}_{2} \mathrm{kk}, \\
\mathrm{O}_{2} \mathrm{klS}, \\
\mathrm{S}_{1} \mathrm{rkV}, \\
\mathrm{S}_{1} \mathrm{jgM}, \\
\mathrm{S}_{2} \mathrm{pdU}\end{array}$ & $\begin{array}{l}1,2,3,4,11 \\
13,14,15 \\
16,17,18, \\
20,21,22, \\
29,32,42\end{array}$ \\
\hline
\end{tabular}




\begin{tabular}{|c|c|c|c|c|c|c|c|c|}
\hline 1 & 2 & 3 & 4 & 5 & 6 & 7 & 8 & 9 \\
\hline & & \begin{tabular}{|l|}
$\begin{array}{l}\text { извест- } \\
\text { няк дет- } \\
\text { ритовый } \\
\text { глини- } \\
\text { стый }\end{array}$ \\
\end{tabular} & $\begin{array}{l}2,30- \\
2,60\end{array}$ & $400-600$ & $15-24$ & 25 & $\mid \begin{array}{l}\mathrm{O}_{2} \mathrm{klS}, \\
\mathrm{S}_{1} \mathrm{rkV}, \\
\mathrm{S}_{1} \mathrm{jgM}\end{array}$ & $\begin{array}{l}21,31,32, \\
42\end{array}$ \\
\hline \multirow{4}{*}{ 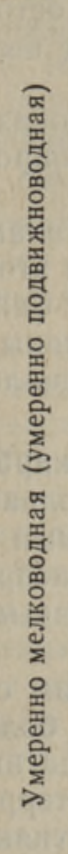 } & \multirow{3}{*}{$\begin{array}{l}\text { Извест- } \\
\text { няки } \\
\text { илисто- } \\
\text { детрн- } \\
\text { товые }\end{array}$} & $\begin{array}{l}\text { извест- } \\
\text { няк или- } \\
\text { сто-дет- } \\
\text { ритовый } \\
\end{array}$ & $\begin{array}{l}2,60- \\
2,75\end{array}$ & $800-1000$ & $10-18$ & $25-50$ & $\begin{array}{l}\mathrm{O}_{2} \text { as, } \mathrm{O}_{2} \mathrm{ls}, \\
\mathrm{O}_{2} \mathrm{kk}, \\
\mathrm{O}_{2} \mathrm{klP} \\
\mathrm{O}_{2} \mathrm{klS}\end{array}$ & $\begin{array}{l}1,2,3,4,5, \\
6,7,8,9,10 \\
11,12,13, \\
14,15,16 \\
\end{array}$ \\
\hline & & \begin{tabular}{|c|} 
извест- \\
няк или- \\
сто-дет- \\
ритовый \\
глини- \\
стый \\
$($ н. о. до \\
$15 \%)$
\end{tabular} & $\begin{array}{l}2,50- \\
2,65\end{array}$ & $400-800$ & $\mid 15-20$ & 25 & $\begin{array}{l}\mathrm{O}_{2} \text { as, } \mathrm{O}_{2} \mathrm{ls}, \\
\mathrm{O}_{2} \mathrm{uh}, \\
\mathrm{O}_{2} \mathrm{kk}, \mathrm{O}_{2} \mathrm{id}, \\
\mathrm{O}_{2} \mathrm{klK}, \\
\mathrm{S}_{1} \mathrm{jrV}\end{array}$ & $\begin{array}{l}1,2,3,4,5 \\
6,7,8,9,10 \\
11,13,14, \\
15,16\end{array}$ \\
\hline & & $\begin{array}{c}\text { то же, } \\
\text { н. о. } \\
>15 \%\end{array}$ & $\frac{2,50-}{2,60}$ & $300-600$ & $20-25$ & 15 & $\begin{array}{l}\mathrm{O}_{1} \mathrm{vlT}, \\
\mathrm{O}_{1} \mathrm{knNm}, \\
\mathrm{O}_{2} \mathrm{uh}, \\
\mathrm{O}_{2} \mathrm{kk}, \mathrm{O}_{2} \mathrm{id}, \\
\mathrm{O}_{2} \mathrm{klK}, \\
\mathrm{S}_{1} \mathrm{jrV}\end{array}$ & 18 \\
\hline & $\begin{array}{l}\text { Извест- } \\
\text { няки } \\
\text { или- } \\
\text { стые }\end{array}$ & $\begin{array}{l}\text { извест- } \\
\text { няк } \\
\text { скрыто- } \\
\text { и микро- } \\
\text { кристал- } \\
\text { лический }\end{array}$ & $\begin{array}{l}2,60- \\
2,65\end{array}$ & $800-1000$ & $10-15$ & $15-25$ & $\begin{array}{l}\mathrm{O}_{2} \text { rk, } \\
\mathrm{O}_{2-3} \mathrm{nb}, \\
\mathrm{S}_{1} \mathrm{jrH}, \\
\mathrm{S}_{1} \mathrm{rkV}, \\
\mathrm{S}_{1} \text { rkK }\end{array}$ & $\begin{array}{l}19,20,30 \\
31,38\end{array}$ \\
\hline \multirow{2}{*}{\multicolumn{2}{|c|}{$\begin{array}{l}\text { Доломиты } \\
\text { вторичные }\end{array}$}} & $\begin{array}{c}\text { доломит } \\
\text { мелко- } \\
\text { и тонко- } \\
\text { кристал- } \\
\text { лический }\end{array}$ & $\begin{array}{l}2,55- \\
2,75\end{array}$ & $800-1400$ & $10-15$ & 25 & $\begin{array}{l}\mathrm{O}_{1} \mathrm{vl}- \\
\mathrm{O}_{2} \mathrm{uh}, \\
\mathrm{O}_{2-3 \mathrm{nb}}, \\
\mathrm{O}_{3} \mathrm{pkR}, \\
\mathrm{S}_{1} \mathrm{rkV}, \\
\mathrm{S}_{1} \text { adM, } \\
\mathrm{S}_{1} \text { jgK, } \\
\mathrm{S}_{1} \text { jgP, } \\
\mathrm{S}_{1} \text { jgM }\end{array}$ & $\begin{array}{l}12,13,14, \\
15,16,22, \\
30,33,34, \\
35,36,37, \\
39,40,41, \\
42,44,45, \\
46,47,48 \\
49,50\end{array}$ \\
\hline & & $\begin{array}{l}\text { доломит } \\
\text { мелко- и } \\
\text { тонко- } \\
\text { кристал- } \\
\text { лический } \\
\text { глини- } \\
\text { стый }\end{array}$ & $\begin{array}{l}2,40- \\
2,50\end{array}$ & $600-800$ & $17-24$ & 25 & $\begin{array}{l}\mathrm{O}_{3} \mathrm{pkR}, \\
\mathrm{S}_{1} \mathrm{rkV}, \\
\mathrm{S}_{1} \text { adM, } \\
\mathrm{S}_{1} \text { jgK, } \\
\mathrm{S}_{\mathrm{i}} \mathrm{jgP}, \\
\mathrm{S}_{1} \mathrm{jgM}, \\
\mathrm{S}_{2} \mathrm{pdH}\end{array}$ & $\begin{array}{l}22,31,34, \\
38,39,40, \\
42,46,48, \\
49,50\end{array}$ \\
\hline
\end{tabular}

* Объяснения к использованным индексам: $\mathrm{O}_{1} \mathrm{vl}-$ волховский горизонт, $\mathrm{O}_{1} \mathrm{vlS}$ - сакаская пачка, $\mathrm{O}_{1} \mathrm{vlKn}$ - кюннапыхъяская пачка, $\mathrm{O}_{1} \mathrm{vlKl}$ - кальвиская пачка, $\mathrm{O}_{1} \mathrm{vlT}$ - телиныммеская пачка, $\mathrm{O}_{1} \mathrm{kn}-$ кундаский горизонт, $\mathrm{O}_{1} \mathrm{knUt}-$ утриаская пачка, $\mathrm{O}_{1} \mathrm{knVl}$ - валгейыэская пачка, $\mathrm{O}_{1} \mathrm{knNm}$ - ныммевескиская пачка, $\mathrm{O}_{1} \mathrm{knNp}$ - напаская пачка, $\mathrm{O}_{2}$ as - азериский горизонт, $\mathrm{O}_{2} \mathrm{ls}$ - ласнамягиский горизонт, $\mathrm{O}_{2} \mathrm{uh}-$ ухакуский горизонт, $\mathrm{O}_{2} \mathrm{kk}$ - кукрузеский горизонт, $\mathrm{O}_{2} \mathrm{id}-$ идавереский горизонт, $\mathrm{O}_{2} \mathrm{klK}$ - куртнаская пачка, $\mathrm{O}_{2} \mathrm{klP}$ - пяэскюлаская пачка, $\mathrm{O}_{2} \mathrm{klS}$ - сауэская пачка, $\mathrm{O}_{2} \mathrm{kl}+\mathrm{onV}$ - вазалеммаская свита; $\mathrm{O}_{2} \mathrm{rk}$ - раквереский горизонт, $\mathrm{O}_{2-3} \mathrm{nb}-$ набалаский горизонт, $\mathrm{O}_{3} \mathrm{pkR}$ - рёаская пачка, $\mathrm{S}_{1} \mathrm{jrV}$ - варболаская свита, $\mathrm{S}_{1} \mathrm{jrTm}$ таммикуская пачка, $\mathrm{S}_{1} \mathrm{jrK}$ - каринуская пачка $\mathrm{S}_{1} \mathrm{jrH}$ - хиллистеская пачка, $\mathrm{S}_{1} \mathrm{rkK}-$ кулламааская пачка, $\mathrm{S}_{1} \mathrm{rkV}$ - вингутаская пачка, $\mathrm{S}_{1} \mathrm{adM}$ - мыхкюлаская пачка, $\mathrm{S}_{1} \mathrm{jgP}$ - пангамягиские слои, $\mathrm{S}_{1} \mathrm{jgS1}$ - селгазеская пачка, $\mathrm{S}_{1} \mathrm{jg} M$ - маазиские слои, $\mathrm{S}_{2} \mathrm{rtKn}$ - куузеныммеские слои, $\mathrm{S}_{2} \mathrm{rtVt}$ - вийтаскне слои, $\mathrm{S}_{2} \mathrm{rtVs}$ - везикуские слои, $\mathrm{S}_{2} \mathrm{pdS}$ - саувереские слои, $\mathrm{S}_{2} \mathrm{pdH}$ - химмистеские слон, $\mathrm{S}_{2} \mathrm{pdKt}$ - катриская пачка, $\mathrm{S}_{2} \mathrm{pdU}$ - удувереская пачка, $\mathrm{S}_{2} \mathrm{~kg} \AA$ - эйгуские слон. 
терригенного материала - в чистых биогермных известняках содержание н. о. менее $3, \mathrm{CaO} 50-55$, в глинистых разновидностях $5-10$ и $43-50 \%$ соответственно. Содержание окиси магния в недоломитизированных биогермных известняках не превышает $3 \%$.

Чистые биогермные известняки являются ценным сырьем для обжига извести, для металлургической и целлюлозно-бумажной промышленности (Teedumäe, 1976). Глинистые биогермные известняки самостоятельно для этого не пригодны, но в определенных случаях могут быть применены совместно с чистыми известняками.

Биогермные известняки (таблица) не отличаются высокими показателями прочности и морозостойкости и пригодны только для низкопрочного щебня марки до 400, Мрз 25.

Залегание биогермных известняков отдельными небольшими телами исключает возможность оконтуривания отдельных месторождений этого типа пород. Совместно с вмещающими их породами, при условии близкого состава и свойств, биогермные известняки вполне перспективны в качестве сырья для известковой и щебеночной, а участками и для целлюлозно-бумажной и металлургической промышленности.

Д е т р и ов е и з в е т н я и встречаются по всему разрезу карбонатных пород Әстонии в виде нрослоев и линз мощностью до нескольких метров. Нередко они ассоциируют с биоморфными, биогермными и илисто-детритовыми известняками. В горизонтальном плане их распространение часто прерывистое, ввиду чего промышленно перспективными можно рассматривать только отдельные уровни (таблица).

Характеризуются детритовые известняки, как правило, высоким содержанием $\mathrm{CaO}(45-55 \%)$, терригенного материала обычно не более $1-3$, окиси магния $0-5 \%$. Более высокие содержания окиси магния связаны со вторичными процессами. Повышенным содержанием терригенного материала (до 10-15\%) отличаются детритовые известняки, образующие «шлейфы» вокруг биогермов (Мянниль, 1960), также некоторые детритовые известняки, развитые в среднем ордовике и нижнем силуре (рисунок; таблица).

По химическому составу детритовые известняки (за исключением глинистых разновидностей) являются пригодными для применения в производстве строительной извести, целлюлозно-бумажной и металлургической промышленности, а также для известкования почв и подкормки птиц.

Физико-механические свойства детритовых известняков (таблица) зависят от размера слагающих их частиц и содержания терригенного компонента. Большей прочностью и морозостойкостью обладают мелкодетритовые известняки с содержанием терригенного компонента до $10 \%$, которые пригодны для производства щебня марки 600, и Мрз 25. Прочность и морозостойкость крупнодетритовых известняков и известняков с содержанием терригенного материала свыше 10\% значительно меньше. Они пригодны для щебня марок 300 и 400, Мрз 15-25. Малоглинистые разновидности детритовых известняков поддаются шлифованию и могут быть применены для изготовления мелких декоративных деталей.

Илисто-детритовы е изв естняки широко распространены как в ордовике (Орвику, 1960; Пылма, 1982), так и в силуре Әстонии (Силур Әстонии, 1970).

Вещественный состав илисто-детритовых известняков разнообразен. Нередко они, особенно менее глинистые разновидности, доломитизированы. Содержание $\mathrm{CaO}$ в недоломитизированных (MgO менее 4,5\%) разновидностях колеблется в пределах $40-50 \%$ и их перспективно использовать в цементном производстве. Для производства воздушной извести они не пригодны из-за высокой глинистости, для производства 
гидравлической извести ограничения создает повышенное (более $2 \%$ ) содержание окиси магния.

Физико-механические свойства илисто-детритовых известняков предопределяются глинистостью. Малоглинистые разновидности (н. о. менее $10 \%$ ) отличаются высокой прочностью независимо от степени доломитизации (таблица) и соответствуют требованиям, предъявляемым для производства щебня марки 800 , Мрз 25-30. Известняки с содержанием н. о. $10-15 \%$ пригодны для щебня марки 600, Мрз 25. Более глинистые разновидности, хотя и соответствуют по прочности сырью для низкопрочного щебня $200-400$, но часто неморозостойки (Мрз 15).

Обстоятельством, значительно ограничивающим возможности использования илисто-детритовых известняков является чередование в разрезе слоев пород с разной глинистостью и присутствие тонких прослоек мергеля.

Илистые известняки. В эту группу входят скрыто- и микрокристаллические известняки с примесью детрита обычно не более $10 \%$ (максимально 25\%). Содержание терригенного компонента в самых чистых разновидностях не превышает $5 \%$, но отмечаются как постепенные, так и послойные переходы в более глинистые известняки с содержанием н. о. до $15 \%$.

Химический состав скрыто- и микрокристаллических известняков вне зон доломитизации отличается высоким содержанием $\mathrm{CaO}(48-52 \%)$, низким содержанием $\mathrm{MgO}$ (до $3 \%$ ) и н. о. (до $5 \%$ ). Они перспективны для применения в металлургической, целлюлозно-бумажной и известковой промышленности, а также для известкования почв и подкормки птиц. В строительных целях перспективны только доломитизированные разновидности с тонкокристаллической структvрой. являясь качественным сырьем для производства щебня марки 600-800, Мрз 25. Афанитовая структура обусловливает гладкую поверхность дробленных зерен щебня и это исключает возможность применения афанитовых известняков в бетонах.

В торичные доломиты. В данную группу соединены все вторичные доломиты, содержащие $\mathrm{MgO}$ более 15 и терригенного компонента менее $10 \%$. В основном это мелко- и тонкокристаллические пористые $(4-15 \%)$ доломиты, которым характерны пленочные прослои доломитового мергеля, редкие гнезда пирита или мелкие кристаллы пирита в рассеянном виде:

Доломиты ордовика, залегающие в виде выдержанных маломошных (до 3-4 м) пластов между известняками, самостоятельного промышленного значения не имеют. То же относится к доломитам, образующим крутопадаюшие или вертикальные тела вдоль линейных тектонических нарушений. Доломиты в пределах упомянутых зон характеризуются невыдержанностью. обусловленной как изменениями состава первичных известняков, так и степенью доломитизации. Кроме того, в пределах долпмитизированных зон породы часто раздроблены, трещиноваты.

Перспективными для промышленного использования являются доломиты, образующие крупные тела, плавно секущие слоистость и располагаюшиеся в верхней части разреза карбонатных пород нижнего силура. Общая мощность доломитовой толщи нижнего силура $20-30$ м. мощность малоглинистых доломитов с содержанием н. о. менее $10 \%$ не превышает 10-15 м. Переход от доломитов к залегаюшим ниже глинистым доломитам и домеритам постепенный и завершается в интервале 2-4 м (Вингисаар. Таалманн, 1974: Кийпли. 1984). Химический состав лоломитов: СаO 29-33. MgO 15-21, н. о. 2-10\%. Наиболее высоким содержанием $\mathrm{MgO}(20-21 \%)$ отличаются доломиты, образовавшиеся по биогермным известнякам. Для них характерно в общем низкое содер- 
жание $\mathrm{Fe}_{2} \mathrm{O}_{3}(0,2-0,5 \%)$, что позволяет их рассматривать в качестве сырья для производства обыкновенного технического стекла. Доломиты, пригодные для производства бесцветного стекла $\left(\mathrm{Fe}_{2} \mathrm{O}_{3}\right.$ менее $\left.0,2 \%\right)$, в разрезе карбонатных пород Эстонии отсутствуют. Малоглинистые доломиты поддаются шлифованию и могут быть применены для производства мелких декоративных деталей.

Физико-механические свойства доломитов высокие (таблица), марка щебня 800-1200, Мрз 25-50. Глинистые доломиты обладают относительно низкой прочностью (таблица) и могут быть применены для производства щебня марки $400-600$, Мрз 25.

Остальные многочисленные литологические разновидности карбонатных пород Эстонии на современном уровне развития промышленности не могут быть рассмотрены как полезные ископаемые.

\section{ЛИТЕРАТ У Р А}

Аалоэ А. Рифовая фация в яагарахуском горизонте силура Эстонин. - Тр. Ин-та геол. АН ЭССР, 1956, вып. 1, 89-94.

Buнгисаар П., Таалманн В. Обзор доломитизации нижнепалеозойских карбонатных пород Эстонин. - Изв. АН ЭССР. Хим. Геол., 1974, 23, № 3, 237-241.

Кийпли $T$. Генезис и распространение промышленных залежей малопримесных известняков и доломитов в Эстонской ССР. - Автореф. канд. дис. Таллин, 1984.

Силур Эстонии. Таллин, 1970.

Мянниль P. Стратиграфия оандуского («вазалемского») горизонта. - Тр. Ин-та геол. АН ӘССР, 1960, вып. 5, 89-122.

Орвику $K$. Литофациальные особенности ордовикских горизонтов волхов (В да $\left(\mathrm{B}_{\mathrm{III}}\right)$ и азери $\left(\mathrm{C}_{\mathrm{II}}\right)$ в северной части Эстонской ССР. - Междунар. геол. конгр. XXI сессии. Докл. сов. геологов. 7. М.-Л., 1960, $71-80$.

Пылма Л. Сравнительная литология карбонатных пород ордовика Северной и Средней Прибалтики. Таллин, 1982.

Тээдумяэ А. Карбонатные породы Әстонской ССР и их рациональное использование. Автореф. канд. дис. Л., 1983.

Эйнасто Р. Строение и условия образования каармаского комплекса лагунных и отмельных отложений (силур Прнбалтики). - Автореф. канд. дис. Л., 1979.

Юргенсон Э. О вещественном составе карбонатных пород тамсалуского горизонта. Тр. Ин-та геол. АН ЭССР, 1961, вып. 6, 29-44.

Vingisaar, P., Oraspōld, A., Einasto, R., Jürgenson, E. Karbonaatkivimite ühtne klassifikatsioon ja legend. Tallinn, 1965.

Teedumäe, A. Eesti NSV karbonaatkivimite ratsionaalse kasutamise skeemist. - Rmt.: Eesti NSV maapōuevarade kaitsest. Tallinn, 1976, 34-41.
Ннститут геологии
Академии наук Эстонской ССР
Поступила в редакцию
$21 / \mathrm{I} 1985$

\section{Aada TEEDUMAE}

\section{EESTI NSV KARBONAATKIVIMITE TÖOSTUSLIKUD TUOBID}

Karbonaatkivimite tööstusliku kasutamise perspektiivi Eesti NSV-s ei määra mitte ainult nende aineline koostis, füüsikalis-mehaanilised omadused, struktuuri ja tekstuuri eripära, vaid ka erinevate omadustega kivimitüüpide ruumilise leviku iseärasused: paksus, pindala, nende muutumise spetsiifika. Lähtudes nimetatud tunnuste kompleksist ning kivimite geneesist, eraldatakse 7 karbonaatkivimite gruppi, mida võib käsitleda kui litoloogilis-tööstuslikke tüüpe, s. t. kui kivimitüüpe, mis Eesti NSV territooriumi geoloogilise ehituse tingimustes on maavarana perspektiivsed.

\section{Aada TEEDUMAE}

\section{INDUSTRIAL TYPES OF CARBONATE ROCKS OF THE ESTONIAN SSR}

The industrial importance of carbonate rocks in the Estonian SSR is determined not only by their material composition, physical qualities, structure and texture, but also by the character of their spatial distribution. Considering all these qualities and genesis, 7 types of carbonate rocks are proposed which are considered to be perspective as mineral wealth. 